\begin{tabular}{|l|l|l|}
\hline \multicolumn{2}{|c|}{ PublisherInfo } \\
\hline \hline PublisherName & $:$ & BioMed Central \\
\hline \hline PublisherLocation & $:$ & London \\
\hline \hline PublisherImprintName & $:$ & BioMed Central \\
\hline \hline
\end{tabular}

\title{
Genetically-modified milk
}

\begin{tabular}{|l|l|l||}
\hline \multicolumn{2}{|c|}{ ArticleInfo } \\
\hline \hline ArticleID & $:$ & 4689 \\
\hline \hline ArticleDOI & $:$ & $10.1186 /$ gb-spotlight-20030131-01 \\
\hline \hline ArticleCitationID & $:$ & spotlight-20030131-01 \\
\hline \hline ArticleSequenceNumber & $:$ & 41 \\
\hline \hline ArticleCategory & $:$ & Research news \\
\hline ArticleFirstPage & $:$ & 1 \\
\hline \hline ArticleLastPage & $:$ & 2 \\
\hline \hline & & RegistrationDate : 2003-1-31 \\
\hline ArticleHistory & $:$ & OnlineDate \\
\hline \hline ArticleCopyright & $:$ & BioMed Central Ltd2003-31 \\
\hline \hline ArticleGrants & $:$ & \\
\hline \hline ArticleContext & $:$ & 130594411 \\
\hline \hline
\end{tabular}




\section{Jonathan B Weitzman}

Email: jonathanweitzman@hotmail.com

Casein is the major protein component of milk and is an important contributor to its nutritional value and processing properties. Bovine milk contains four casein proteins that aggregate into large colloidal micelles to give milk its particular functional characteristics. In an Advanced Online Publication in Nature Biotechnology Brophy and colleagues at the Ruakura Research Centre in New Zealand describe the use of transgenic and nuclear-transfer technologies to create cloned cows with altered casein production (Nature Biotechnology, 27 January 2003, doi;10.1038/nbt783). Brophy et al. engineered female bovine fetal fibroblasts to express transgenes encoding for bovine $\beta$ - and $\kappa$-casein (CSN2 and $C S N 3$ genes). The modified cell lines were used to created eleven cloned calves. Milk from the cloned animals was enriched for transgene-derived caseins, demonstrating the potential of this technology to make better milk.

\section{References}

1. Nature Biotechnology, [http://www.nature.com/naturebiotechnology]

2. Ruakura Research Centre, [http://www.agresearch.co.nz]

3. Cloned transgenic calves produced from nonquiescent fetal fibroblasts. 